\title{
Grammatical metaphor: What do we mean? What exactly are we researching?
}

Devo Y Devrim

Correspondence:

ddevrim@une.edu.au

School of Education, University of

New England, Armidale 2351,

Australia

\section{Springer}

\begin{abstract}
This paper aims to explore grammatical metaphor (GM) from a theoretical perspective. In order to achieve this, the paper firstly presents two models that theorize GM, namely the stratal model (Halliday, 1985a, 1988, 1998; Martin, 1992a, 1993b; Halliday \& Martin, 1993) and the semantic model (Halliday \& Matthiessen, 1999). GM types and instances show differences according to the model that theorizes GM; the paper, therefore, will explore the types and instances of GM. This will be followed by research studies that investigated the development of GM in language development and language education in order to present how GM theorization has been applied in literature. Finally, the paper will recount of a recent research study (Devrim, 2013) that aimed to develop an approach to teaching GM using an integrated model. The paper will conclude with a discussion and pedagogical implications for researchers and educators.
\end{abstract}

\section{Background}

Grammatical metaphor (GM hereafter), which was suggested by Halliday (1985a) is one of the most important characteristics of academic, bureaucratic and scientific discourses and it is one of the crucial contributions of Systemic Functional Linguistics (SFL hereafter) to the field of linguistics and education. However, GM theory has evolved since its suggestion and there are two models that theorize GM. Depending on which theory researchers draw on, the instances of GM differ dramatically. Therefore, this paper firstly aims to explore GM from a theoretical perspective and then it will move on to the application of the theory in language development and language education studies.

In SFL theory, two models that theorize GM have been suggested: the stratal model (Halliday, Halliday 1985a, Halliday 1988, Halliday 1998; Martin, Martin 1992a, Martin 1993b; Halliday \& Martin, 1993) and the semantic model (Halliday \& Matthiessen, 1999). The definition and types of GM vary according to each model, as the notions of stratal tension and semantic junction draw on different linguistic configurations that lead to GM. It is also important to note that although the stratal and semantic models differ in their theorization and definition of GM, they relate to each other quite closely. Actually, the semantic model is a development of the stratal model. In other words, grammatical metaphor examined in the semantic model can be viewed as the result of transference and/or transcategorization of GM discussed in the stratal model (see Halliday, 1998). The models will be discussed in relation to how they define and categorize GM, the theoretical part will be

(c) 2015 Devrim; licensee Springer. This is an Open Access article distributed under the terms of the Creative Commons Attribution License (http://creativecommons.org/licenses/by/4.0), which permits unrestricted use, distribution, and reproduction in any medium, provided the original work is properly credited. 
followed by studies conducted in language development (Christie \& Derewianka, 2008; Derewianka 2003a; Painter, 2003; Torr \& Simpson, 2003) and language education (Byrnes, 2009; Colombi, 2006; Mohan \& Beckett, 2001; Ryshina-Pankova, 2010; Schleppegrell, 2004;) that explore GM. Following the discussion of the application of stratal and semantic models to language development and language education, another more comprehensive study that aimed to develop an integrated model to theorize GM will be visited (Devrim, 2013). This section will also explore how an integrated model, which draws on both stratal and semantic models, is helpful in the teaching of GM. The paper will conclude with implications for GM researchers and educators.

\section{Stratal model: definition and types of GM}

The stratal model theorizes GM in relation to the stratal tension between discourse semantics and lexicogrammar (Halliday 1985a, Halliday 1988, Halliday 1998; Martin 1992a, Martin 1993b; Halliday \& Martin, 1993). The definition of GM from the perspective of the stratal model might be the resetting of the relationship between discourse semantics and lexicogrammar creating a stratal tension. According to Martin (1993b), p. 112.

Grammatical metaphor can thus be seen to introduce a tension between grammar (a text's wording) and semantics (a text's meaning) so that the language has to be read on at least two levels (i.e. metaphorically), with one level directly reflecting the grammar, and beyond that another symbolically related level of semantics.

Due to the stratal tension between semantic categories and their realization in lexicogrammar, GM needs to be read metaphorically and congruently.

The two main GM categories within the stratal model are interpersonal and ideational metaphors (Halliday 1985a). Interpersonal metaphor consists of metaphors of mood and metaphors of modality. Ideational metaphor is categorized into two types, namely, experiential and logical metaphors (Martin 1992a). Each GM type will be explicated below with examples.

Interpersonal metaphor is categorized into metaphors of mood and modality, creating a stratal tension between discourse semantics and lexicogrammar. Mood metaphors construe a discourse semantic speech function through an incongruent mood option in grammar. To illustrate, the speech function command might be realized as a command, e.g. get up, using imperative mood. Alternatively, command might also be realized as a suggestion as in "why don't you get up?", using interrogative mood. Mood metaphors are found more commonly in spoken language. However, the second type of interpersonal metaphor, metaphors of modality, is more likely to be found in written language.

Metaphors of modality realize non-congruent ways of speech function (Halliday 1985a). Modality refers to the area between positive and negative polarity, i.e. to the cline between "yes" and "no". Modality is congruently realized by modal finite, e.g. can, may, could, should, and mood adjuncts, e.g. possibly, probably. These instances are implicit ways of realizing speech function in grammar and considered congruent, as they do not create stratal tension. Alternatively, speech function might be projected in a clause complex explicitly, creating stratal tension, e.g. I believe ..., I think ..., it is possible to argue that ..., it is obvious that ..... The first two of these examples are referred to as explicit subjective, whereas the other two are considered explicit objective (Halliday 1985a). The congruent 
realization of speech function takes place within clause through modal verbs such as can, may, could and might (implicit modal) or through modal adjuncts, e.g. possibly or probably (implicit mood adjunct). Alternatively, speech function can be realized within the modality system through projecting clause complexes consisting of mental and idea clauses, e.g. "I think...", "I believe" (explicit subjective) or objectively such as "It is possible to argue that..." (explicit objective).

Ideational metaphors are theorized as consisting of two kinds, experiential and logical (Martin 1992a). This separation is based on the stratified language model suggested by Halliday \& Hasan (1976) and Halliday (1985a). Experiential metaphor is considered the metaphorical ways of meaning making where process (with a small $\mathrm{p}$ ) is realized by a noun, and quality is realized by an adjective in lexicogrammar. Logical metaphor is the metaphorical ways of realizing the consequential and temporal relations inside clauses (Martin 1992a). According to Martin (1992a), logical and experiential metaphors cooperate when external conjunctive relations are realized metaphorically and "this interaction produces a high level of abstraction in text, making it inaccessible to large sections of the community" (Martin 1992a, p. 407). The following example by Halliday (1985a), p. 329 shows how the meanings are packed into nominal groups, forming GM instances; and how the causal relation between clauses realized within the clause.

\section{Example 1}

a. Because technology is getting better, people are able to write business programs faster.

b. Because technology is advancing, people are (becoming) able to write business programs faster.

c. Advances in technology are enabling people to write business programs faster.

d. Advances in technology are making the writing of business programs faster.

e. Advances in technology are speeding up the writing of business programs.

Example 1 illustrates how experiential and logical meanings become more metaphorical. The processes in the first sentence, "getting better" and "writing", become nouns in the last sentence. In other words, the experiential meanings are packed into nominal groups, i.e. "advances in technology" and "the writing of business programs"; also the logical meaning which is realized by the conjunction "because" is realized in a verbal group, e.g. "speeding up".

Following Halliday, Martin (1992a) distinguishes between logical and experiential metaphor as two kinds of ideational metaphors. Experiential metaphors refer to actions/processes or qualities of things realized as Things in texts, whereas logical metaphors build logical relations within clause, as in the example below:

\section{Example 2}

The enlargement of Australia's steel-making capacity, and of chemicals, rubber, metal goods, and motor vehicles all owed something to the demands of war. (p. 407).

The actions/processes (to enlarge, to demand) are formulated as Things (enlargement, demand) and the consequential relationship between them is construed by the use of 
the word "owed" in the above example. However, it is possible to formulate Things as actions/processes, and build the logical relationship between clauses by using conjunctions.

\section{Semantic Model: Definition and types of GM}

The second model that theorizes GM is known as the semantic model, which was suggested by Halliday \& Matthiessen (1999). Halliday \& Matthiessen (1999), p. 238 account for the congruent and metaphorical realization of semantic categories in grammar:

When a sequence is realized as a clause complex, or a process as a verb, this is congruent: it is the clause complex, and the verb, in the function in which it evolved. When a sequence is realized as something other than a clause complex, or a process as something other than a verb, this is metaphorical. Some other grammatical unit is supplanting them in these functions.

The highest in rank order in semantics is sequence, followed by figure and elements of figures. The elements of figures are participant, process, circumstance and relator. The above explanation states that sequence is realized congruently by clause complex, and process (as a semantic category) is realized congruently by a verb in grammar. Thus, according to the semantic model, if sequence is realized by a clause or if a noun realizes a process in grammar, then the linguistic structure is called a GM instance.

Based on the congruent and metaphorical realization of semantic categories, Halliday and Matthiessen (1999), p. 244 refer to the notion of semantic junction. Consequently, Halliday and Matthiessen base their categorization of GM in relation to the joining of semantic categories. Halliday \& Matthiessen (1999), p. 244 suggest that:

It seems to be necessary to identify the types of grammatical metaphor and characterize them explicitly in relation to the semantics as a whole. We therefore introduce a general distinction between metaphoric (elements of features) and others. Metaphoric elements, as we said above, are junctional in that they embody a junction of two semantic categories... Junctional elements will always have two categories in their description, e.g. 'process thing,' 'circumstantial quality,',relator process'.

Particularly the elements forming Figs. in discourse semantics might be assigned double roles such as "process thing" or "relator process". Halliday \& Matthiessen (1999) see two semantic meanings are coming together rather than stratal tension being created. Therefore, from this perspective, GM might be defined as the grammatical structures that result from the semantic junction between elemental semantic categories.

The semantic model suggests 13 types of ideational metaphors based on elemental semantic categories. Halliday and Matthiessen (1999) theorize GM using the concept of semantic junction, which allows them to base their categorization of GM in relation to metaphorical shifts of elemental classes. Table 1 illustrates the 13 types of GM suggested by Halliday \& Matthiessen.

Table 1 shows how elemental semantic categories are realized due to the notion of semantic junction. Elemental categories, quality, process, circumstance, relator, an empty 
Table 1 Domains of elemental metaphors (Halliday \& Matthiessen, 1999, p. 245)

\begin{tabular}{|c|c|c|c|c|}
\hline \multirow[t]{2}{*}{ Congruent: } & \multicolumn{4}{|l|}{ Metaphorical } \\
\hline & $\rightarrow$ Circumstance & $\rightarrow$ Process & $\rightarrow$ Quality & $\rightarrow$ Thing \\
\hline Quality $\rightarrow$ unstable & & & & 1 instability \\
\hline Process $\boldsymbol{\rightarrow}$ absorb & & & 3 absorptive & 2 absorption \\
\hline $\begin{array}{l}\text { Circumstance } \rightarrow \text { instead of; on } \\
\text { the surface }\end{array}$ & & 6 replaces & $\begin{array}{l}5 \text { alternative; } \\
\text { superficial }\end{array}$ & $\begin{array}{l}4 \\
\text { replacement; } \\
\text { surface }\end{array}$ \\
\hline $\begin{array}{l}\text { Relator for/because } \vec{\rightarrow}[b, \text { for } / \\
\text { because } a] \text { so }[a, \text { so } b]\end{array}$ & $\begin{array}{l}10 \text { because of; as a } \\
\text { result }\end{array}$ & $\begin{array}{l}9 \text { causes, proves; } \\
\text { ensues, follows from }\end{array}$ & $\begin{array}{l}8 \text { casual; } \\
\text { consequent }\end{array}$ & $\begin{array}{l}7 \text { cause, proof; } \\
\text { result }\end{array}$ \\
\hline$\varnothing$ & & $\begin{array}{l}12 \text { occurs; imposes; } \\
\text { does, has }\end{array}$ & & $\begin{array}{l}11 \\
\text { phenomenon, } \\
\text { fact }\end{array}$ \\
\hline $\begin{array}{l}\text { Thing, circumstance } \rightarrow \text { drive [be } \\
\text { safe] decided [today] }\end{array}$ & \multicolumn{4}{|c|}{$\begin{array}{l}13 \text { expansion of Thing < in Environment of } 1 \text { or } 2>\text { driver [safety] driver's } \\
\text { [safety] [safety of the driver] today's [decision] [decision] of today }\end{array}$} \\
\hline
\end{tabular}

category, thing and circumstance are placed with congruent examples in the first column. Columns 2 to 5 illustrate how joining elemental categories create GM instances. Type 1 results from the joining of quality with thing, and is referred to as "quality thing". Type 2 represents the joining of process and thing, and might be called "process thing". Type 3 depends on the semantic junction of process and quality, thus it is refereed to as "process quality". Types 4, 5 and 6 present how circumstance joins with thing, quality and process creating semantic junction. Types 7, 8, 9 and 10 represent the semantic junction of relator and thing with process, quality, and circumstance. Types 11 and 12 represent the semantic junction of an empty category and thing with process (N.B. although Halliday \& Matthiessen do not define an empty category as an element). Moreover, Type 13 is an extension of the environments of Type 1 and Type 2.

In addition, Halliday and Matthiessen (1999) underscore that the relation between congruent and metaphorical ways of meaning making is similar to inter-stratal realization. However, the relation needs to be considered as intra-stratal due to the fact that the relation is between different meanings in semantics. This view is in opposition to the stratal model that claims GM results from the stratal tension between discourse and lexicogrammar. Halliday and Matthiessen (1999), p. 288 posit that:

The metaphorical relation is thus similar to inter-stratal realization in that it construes a token-value type of relation. Here, however, the relation is intra-stratal: the identity holds between different meanings, not between meanings and wordings.

In the above elucidation, the realization of GM is due to the relationship between elements in semantics. According to the semantic model, GM does not result from the inter-stratal relationship between discourse semantics and lexicogrammar, but rather from an intra-stratal relationship between elemental semantic categories. In other words, Halliday \& Matthiessen assign the meaning-making process entirely to the discourse semantic stratum.

\section{Methods: Summarizing research on GM in relation to model employed}

Having visited the existing theorization of GM, this section will explore research studies conducted on GM that focus on language development and language education. 
The studies will be summarized in relation to their context, data collection, findings and GM model, and this will be done distinguishing the research studies based on their theoretical orientation (Byrnes 2009; Colombi 2006; Christie and Derewianka, 2008; Derewianka 2003a; Mohan \& Beckett, 2001; Painter 2003; Ryshina-Pankova 2010; Schleppegrell, 2004; Torr \& Simpson, 2003). The reason why these particular studies are included in this paper is due to the publication year of the studies. The studies conducted following the emergence of the semantic model were included in order to reach a more comprehensive picture of GM theorization and application.

\section{Results}

\section{GM research based on stratal model}

The studies exploring GM that adopt the notion of stratal model outnumber the studies that adopt the notion of semantic junction. These studies explore both language development and language education (Colombi 2006; Christie and Derewianka, 2008; Mohan \& Beckett, 2001; Painter 2003; Ryshina-Pankova 2010; Schleppegrell, 2004; Torr \& Simpson, 2003).

\section{Colombi 2006. Grammatical metaphor: Academic language in Latino students in Spanish}

The paper presents three types of GM as a way of explicating and tracing the development of academic language at the college level in heritage speakers of Spanish. These types are (1) ideational GM, an incongruent representation of experiential meaning; (2) logical GM, a way of organizing ideas at the level of discourse in an incongruent manner; and (3) interpersonal GM, which presents authorship in the text both implicitly and explicitly. The study explores the use of GM in Spanish as a heritage language in the U.S. The data come from students' writing and oral presentations for a period of a year in a program of Spanish for Native Speakers that aimed to develop Spanish literacy. The findings from the study suggest that GM is a prestigious feature of academic literacy in Spanish and proficient Spanish users employ ideational, logical and interpersonal GM in an effective way.

\section{Christie and Derewianka 2008. School Discourse: Learning to Write across the Years of} Schooling

In their book, Christie and Derewianka present their findings from various disciplines and genres based on the data consisting of texts from Australian primary and secondary school students. The question how primary and secondary school students ameliorate writing skills is put under lens through the documentation of student texts with meticulous analysis. The researchers concentrate on three school subjects, namely English, history and science. The data consisting of student texts in various genres from grade 1 to grade 12 are analysed using SFL theory. The documentation of writing development across years in the school subjects under investigation led the researchers to propose a framework for writing programs in various school subjects. Christie and Derewianka summarize how writing develops across school subjects through years. The development of experiential, logical, interpersonal and textual linguistic resources in student writing is illustrated in relation to developmental phases, i.e. early childhood, late childhood, mid-adolescence and late adolescence. Furthermore, each school subject is meticulously investigated to compare and contrast the use of major linguistic features 
by various age groups. In their analysis, Christie and Derewianka also explore how GM develops in relation to literacy.

Mohan \& Beckett 2001. A functional approach to research on content-based language learning: recasts in casual explanations

Mohan and Beckett explore how content-based language learning (CBLL) is applied at tertiary level in Canada from an SFL perspective. According to the researchers, SFL provides rather robust theoretical background to CBLL as compared to focus on form or traditional approaches to language learning. Mohan and Beckett analyse the grammatical scaffolding of casual explanations, focusing on the lexicogrammar of causal meaning and the place of GM in recasts. The data for this study comes form the consultations between a teacher and three third-year-exchange students from Japan with high intermediate level of English language proficiency. Having analysed the teacher-student interactions in detail, the researchers conclude that SFL offers richer theoretical approach to CBLL. Especially, the tools provided by SFL are crucial in analysing advanced language development of ESL writers/ speakers. Mohan and Beckett conclude how scaffolding helps the students to improve their use of metaphorical causality (logical metaphor).

Painter 2003. The use of a metaphorical mode of meaning in early language development

This study is conducted to explore how native-English-speaking children develop their use of metaphorical meaning making, drawing on Halliday (1994, Halliday 1998). Painter investigates the language development of his sons', Hal and Stephen, metaphorical language use. The data consist of audio and notebook recordings of children's spontaneous speech. Hal's language development was investigated from 7 months to $2 \frac{1}{2}$ years of age, whereas Stephen's language development was explored from the age of $2 \frac{1 / 2}{2}$ years to 5 . The landmark development in language development leading to GM was the ability to use a word to mean an imaginary situation and to employ a word to refer to a representation other than a thing. Following these developments, children started using GM of the adult language. The first important construction was Process ${ }^{\wedge}$ Range structures that are used in everyday speech such as have a bath, have a cuddle etc. Although these structures lost their metaphorical meaning and are referred to as 'dead' or 'faded' metaphors, they are still important leading to the use of 'living' or 'bright' metaphors. The children went on to use embedded clauses following dead metaphors. The embedded clauses pave the pathways to nominalization. The findings illustrate that the earliest context for GM development is the use of Postmodifiers within nominal groups and this is followed by the use of demonstratives for text reference.

Ryshina-Pankova 2010. Towards mastering the discourses of reasoning; Use of grammatical metaphor at advanced levels of foreign language acquisition

Ryshina-Pankova presents how GM is used by native and non-native speakers of German at Georgetown University in the U.S. The study was conducted on the three levels (Levels 3, 4, and 5) of the Georgetown University undergraduate Foreign Language Program that constitute the upper or advanced levels of this content-oriented, task-based, and genre-informed curriculum. The data comes from 55 book reviews written by advanced German users and 30 book reviews composed by native German users. The study particularly investigates how GM use contributes to the overall 
coherence and cohesion of book reviews. Both quantitative and qualitative analyses of book reviews suggest that the instances of GM increase when the proficiency level increases (from Level 3 to Level 5 in comparison to native German speakers' GM deployment). As a result, the book reviews with effective GM use result in rhetorically successful texts, and this suggests GM is rather important in a German as an additional language context.

\section{Schleppegrell 2004. Technical writing in a second language: the role of grammatical metaphor}

This study was conducted within the U.S. context where children or adolescents who arrived in the States as immigrants were under the lens. These children and teenagers are referred as users of English as a second language and their written language features at tertiary level are explored within the theoretical framework of SFL. The research analyses how students employ GM in chemical engineering laboratory reports. Drawing on Halliday 1994 (Halliday 1998) and Martin (1992a), Schleppegrell emphasizes the roles of GM as technicality, reasoning within clause, text structuring and construing authoritativeness. These four roles correspond to experiential, logical, interpersonal and textual metaphors. The author compares and analyses the lab reports of three ESL writers and a proficient writer who is a 'native speaker' of English. The lab reports are broken down into phases for the students to construe what they have achieved during the lab sessions. The major sections include abstract, introduction, theory, experimental methods, results, discussion and conclusions. The findings from the study suggest that the ESL writers experience difficulty in using GM effectively as compared to the proficient writer. The study also implies GM is a rather crucial linguistic construct that help writers improve their written work.

Torr and Simpson 2003. The emergence of grammatical metaphor: literacy-oriented expressions in the everyday speech of young children

Torr and Simpson investigated the ways in which GM emerges during interactions of native-English speaking children with their caretakers. Specifically, the researchers concentrated on the following issues: how GM emerges, what GM types are deployed by children, what kind of related grammatical patterns foster the use of GM and the context in which GM occurs. All the children were members of middle class families. In addition to the emergence of GM, the data was also analysed based on the use of modal expressions as well as transcategorised constructs, which are closely related to GM. The researchers categorize the data into four developmental phases with evident trends. The language of children between 1:8 to 2:0 years, from 2:0 to 3:0, from 3:0 to 4:0 and from 4:0 to 5:0 years of age. The results from the study suggest that GM starts and emerges in interpersonal contexts prior to schooling. This mainly depends on the development of mood and modality systems prior to the transitivity system. Although the children use dead metaphors, the use of GM as nominalization is rather rare and restricted to the adult use with no original production.

\section{GM research based on semantic model}

Byrnes 2009. Emergent L2 German ability in a curricular context: a longitudinal study of grammatical metaphor

This study investigates the ways in which the learners of German as a second language develop their use of GM in three consecutive semesters. Based on the researcher's 
assumption that the threshold language proficiency level for effective GM use is the intermediate level, the language development of 14 students has been tracked at intermediate, high intermediate and advanced levels. The students were assigned three writing tasks at each level that comprise the data for the study. While they were at the intermediate level, the studnets were required to compose a narrative, then they were to complete a journalistic report at the high intermediate level and finally at the advanced level, they were assigned to create a written version of an argumentative speech. To code the data, Byrnes concentrated on three important linguistic aspects that are closely related to GM, specifically derivations, rank shift and agnation. The qualitative and quantitative analyses suggest that the texts become more complex when the level of proficiency increases, and the number of GM increases depending on the level of proficiency. As for the qualitative analysis, the researcher selects one student to analyse his literacy development focusing on GM. Based on the longitudinal analysis of 14 students, the researcher concludes that GM is a rather important construct in the learning of German as a second language. Also, the genre-based pedagogy inspired by SFL suggests essential means to teach an additional language.

\section{GM research based on stratal and semantic models}

\section{Derewianka 2003a. Grammatical metaphor in the transition to adolescence}

Derewianka explored the ontogenetical development of the occurrence of GM from childhood to adolescence. To track the development, the researcher analyses his sons' use of GM in written texts from the age of 5 to 13 drawing on Halliday \& Matthiessen (1999). The texts produces by the kids were categorized according to genre and complemented by observations, field notes, interviews and recordings of oral interaction during the production of written texts. Prior to this analysis, she identifies the gateways to GM. The first gateway to GM is the playing with the interstratal relationship as in puns, followed by lexical metaphor, transcategorization as a linguistic process leading to GM, rankshifted embeddings, faded metaphor and technical terms. These processes pave the pathways to the entry to adult language. The findings illustrate that there is a significant increase in the use of GM at the age of 9, before puberty. This finding contradicts with Halliday's claim that the use of GM considerably increases during the onset of puberty and entry to secondary school. However, the study confirms Halliday's claim that language development follows the following phases; generalization, abstraction and GM.

This section summarized the research studies from the fields of language development and language education. In order to provide a broad picture regarding the application of GM theory, each study was summarized in relation to its aims, context, data, and findings. The majority of the studies presented in this section adopt the stratal model as the theoretical orientation using various references (Colombi 2006; Christie and Derewianka, 2008; Mohan \& Beckett, 2001; Painter 2003; Ryshina-Pankova 2010; Schleppegrell, 2004; Torr \& Simpson, 2003). There is only one study that used the semantic model as the theoretical orientation (Byrnes, 2009), and there is only one study that adopted both models to analyse GM development (Derewianka 2003a).

Although all these studies are rather important in relation to the application of GM theory to language development and language education, they have a major drawback. 
They do not explicitly state the theoretical orientation that leads them to GM analysis. As GM is theorized in two different ways, the types of GM also differ depending on the model adopted. Explicitly stating the model used in each study would make it much easier for the practitioners, e.g. discourse analysts and language educators, to grasp how GM develops in various contexts.

The following section will introduce an integrated model with an aim to develop an approach to teaching GM (Devrim, 2013). The study differs from the previous studies that explore GM in two ways. Firstly, it retheorizes GM based on the two existing models. Secondly, this particular study has a pedagogical orientation, as it aims to develop an approach to teaching GM.

\section{Towards an integrated model}

\section{Devrim 2013. Development of grammatical metaphor in academic literacy through online} language support

This research study was conducted within the Scaffolding Literary in Adult and Tertiary Environment (SLATE) Project, which was jointly conducted by the City University of Hong Kong and the University of Sydney (Mahboob et al. 2010). The SLATE project was based on the previous work conducted within the Sydney School's genre-based pedagogy, which integrated SFL-inspired genre theory (Martin \& Rose, 2008), sociology of education (Bernstein, 1975) and sociocultural theory (Vygotsky, 1978), and applied these insights into an online teaching/learning environment. This particular study specifically focused on how students develop their GM use with the help of tutors' feedback and aimed at developing an approach to teach GM. As GM is a fundamental characteristic of science, bureaucratic and academic registers (Halliday 1985a), mastery of GM can lead to success in academic and educational environments for additional language users. Therefore, developing an approach to teaching GM to second language users is essential. The study was framed as an action research based on the action research cycle (Kemmis \& McTaggart, 1988; Freebody, 2003; Burns, 2010). The action research cycles spanned a period of three years, between 2008 and 2010.

Phase 1 of the project focused on laboratory reports of undergraduate students enrolled in the Department of Applied Physics. Phase 2 concentrated on compositional reports of the students who were enrolled in the Department of Electronic Engineering. Different from Phase 1, however, Phase 2 involved tutor training and the provision of background knowledge about GM at clause level to students. Thus, the approach adopted during this phase was interventionist. The last phase of this action research project, Phase 3, explored students' assignments written as explanation of the impacts (effects/consequences) of nominalization on language were explained. These students were enrolled in the Department of Linguistics. During this phase, the tutors were trained to provide feedback on experiential and logical metaphors. However, different from Phase 2, the tutor training was directed at periodicity at the whole text level (Martin \& Rose, 2003). The results from the three phases of the action research project suggest that the training provided to tutors was effective in increasing the number of instances of GM feedback that resulted in text revisions. Furthermore, the training provided to tutors at the whole text level was more effective in Phase 3 than in Phase 2. Therefore, this action research recommended that tutors that support ESL writers' academic literacy skills need to be trained in GM. Furthermore, GM training is more 
effective when it is designed in relation to periodicity at the whole text level. In other words, when GM is taught to students and tutors based information flow at the whole text level (macro-Theme, macro-New, hyper-Theme, and hyper-New), it generates more instances of GM instances and GM feedback. In other to reach these findings, the researcher needed to retheorize GM based on the existing models. The following subsections present the theorization, types and instances of GM based on an integrated model.

\section{Definition and types of GM based on an integrated model}

GM might be defined from the perspective of an integrated model as follows: GM is a linguistic structure that results from the stratal tension between ideational (experiential and logical) and interpersonal meanings in discourse semantics, and lexicogrammar. The above definition opens up room for the theorization of interpersonal metaphor and emphasizes a differentiation between experiential and logical metaphors.

Consider the following set of examples where logical relations are realized inside clauses. The logical metaphors are in boldface and experiential metaphors are underlined.

\section{Example 3}

The passing of a new bill caused anxiety among taxpayers.

Anxiety among taxpayers is due to the passing of a new bill.

The passing of a new bill is causal to anxiety among taxpayers.

The cause of anxiety among taxpayers is the passing of a new bill.

In Example 3, logical relations are realized inside clauses by verb, preposition, noun and adjective (Halliday, 1998). The use of logical metaphor necessitates the use of experiential metaphors. The experiential metaphor instances in the above example are "passing" and "anxiety" that are realized by nominal groups. The logical metaphor instances, "caused", "due to", "causal" and "cause", realize causality inside clauses. In Example 3, there is not a congruent relationship between the discourse semantics stratum and the lexicogrammar stratum where processes and qualities are realized by nouns rather than verbs and adjectives. Fig. 1 below illustrates the metaphorical relationship between discourse semantics and lexicogrammar. The relationship is not typical or regular; technically speaking it is not congruent.

Figure 1 shows how process, quality and logical relations create GM through stratal tension (adapted from Martin, 1993b). The semantic categories process and quality are realized by noun and verb; and logical relations are realized by noun, verb, adjective and preposition in grammar. Experiential metaphor, thus, is categorized as process as noun, e.g. "passing" and quality as noun, e.g. "anxiety". Logical metaphor is categorized into four types; cause as verb, e.g. "cause", "lead to"; cause as noun, e.g. "cause", "impact"; cause as adjective, e.g. "causal", "resultant"; and cause as preposition, e.g. "due to", "through".

Alternately, the clauses in Example 3 might be worded congruently by realizing process by verb, quality by adjective, and logical relations by conjunctions. Consider the following example.

\section{Example 4}

The taxpayers are anxious, because the government passed a new bill.

The taxpayers are anxious because a new bill was passed. 


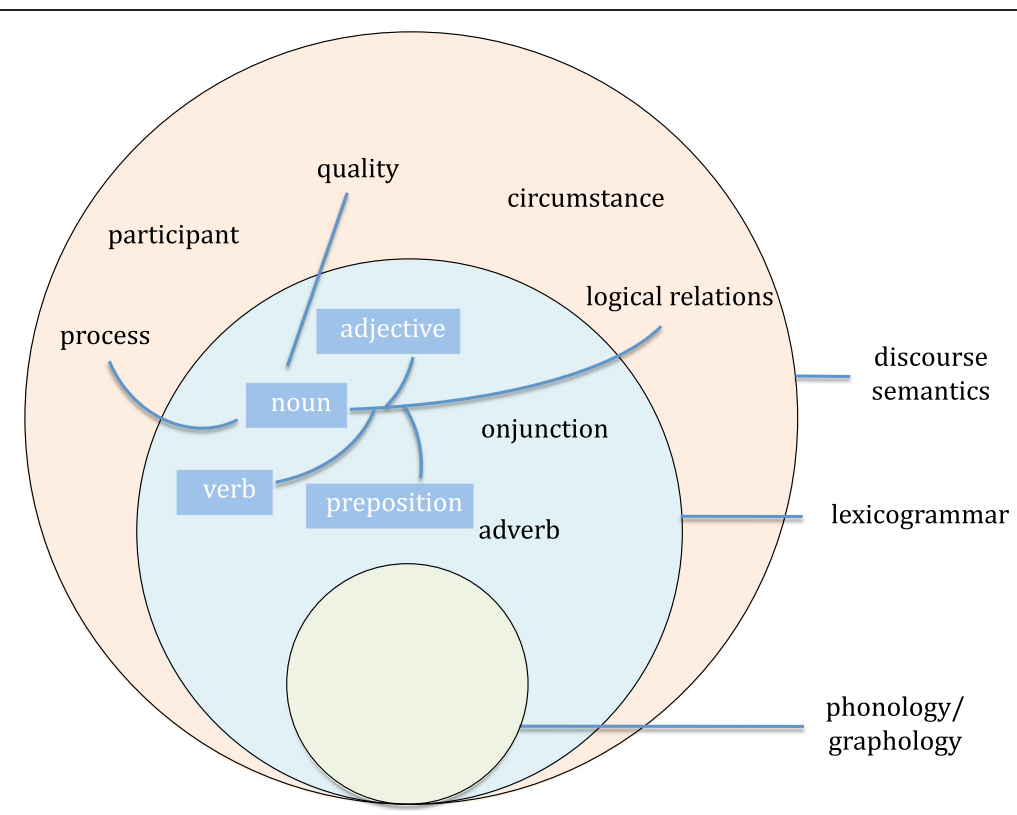

Fig. 1 Metaphorical realization of the ideational domain of discourse semantics (Devrim, 2013, p. 36)

Example 4 shows how the discourse semantic categories process, quality and logical relations are realized congruently by verb, adjective and conjunction, respectively. Fig. 2 illustrates how discourse semantics is congruently mapped on to lexicogrammar.

As it is shown in Fig. 2 (adapted from Martin, 1993b), the semantic units process, participant, quality and circumstance, and logical relations are congruently realized in grammar by verb, noun, adjective, preposition and adverbials, and conjunction respectively.

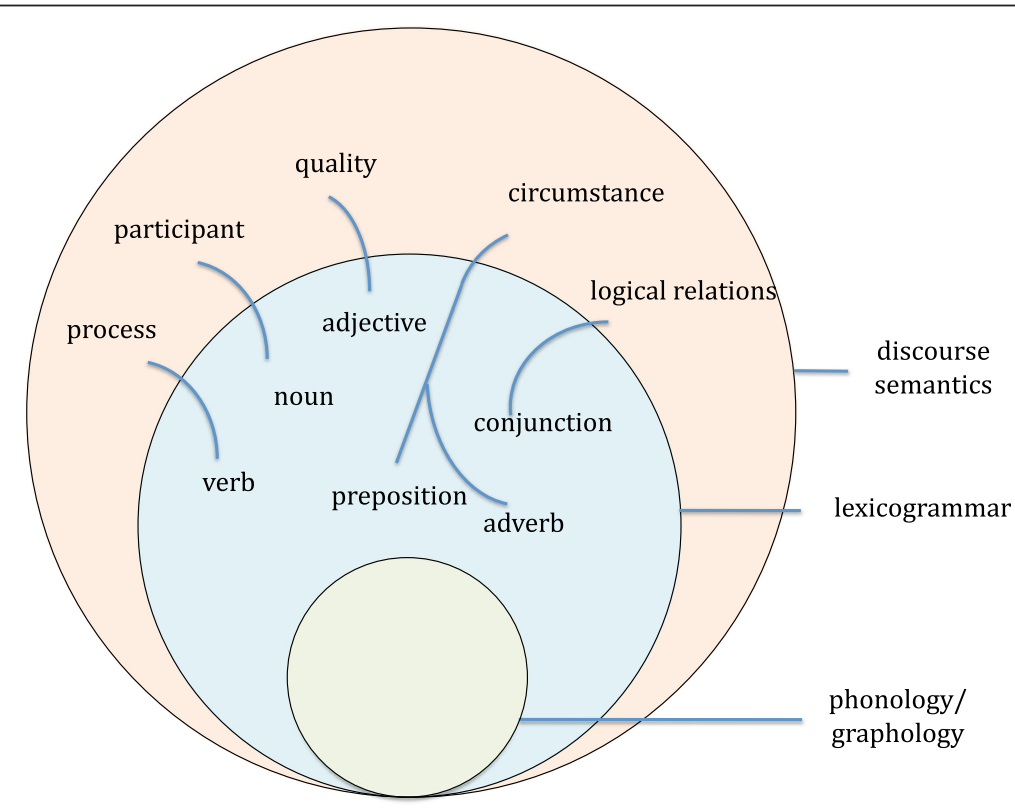

Fig. 2 Congruent realization of the ideational domain of discourse semantics (Devrim, 2013, p. 37) 


\section{Discussion}

An integrated model was developed with an aim to cultivate an approach to teaching GM and it is rhetorically oriented (Devrim, 2013). In other words, an integrated model situates GM within English as a second language (ESL) context and focuses on the text types that various cohorts that took part in the study were expected to compose. This requires drawing on the previous two models that theorize GM. The model builds on the idea that GM is the resultant of a stratal tension to be able to theorize experiential and logical metaphors, and the semantic model to include all types of logical metaphor. This has been done due to various reasons.

Firstly, the categorization of ideational metaphor into experiential and logical metaphors by the stratal model is simpler, thus it is more appliable to the teaching of GM. The stratal model categorizes ideational metaphor into experiential and logical metaphors with a total of six types. On the other hand, the ideational metaphor types suggested by the semantic model create difficulties for developing an approach to teaching GM due to its delicacy and complexity consisting of thirteen major types. Second, only the stratal model theorizes interpersonal metaphors, because interpersonal metaphors result from the non-congruent realization of speech function by the modality system in lexicogrammar. Next, the stratal model provides an explanation for technical terms and dead metaphors. These structures can only be explained due to the loss of stratal tension. In other words, metaphorical forms become technicalized or fade away when they become congruent. Therefore, a model that theorizes GM should also account for interpersonal metaphors, technical terms and dead metaphors. Finally, an integrated model discussed here draws on the semantic model as well. The types of metaphorical causality (logical metaphor) include all the possible types (cause as verb, cause as noun, cause as adjective and cause as preposition). Therefore, an integrated model that retheorizes GM draws on both models due to its pedagogical objective.

This particular study aims to make the theoretical orientation explicit. Not only does the study make the theoretical orientation explicit, but it also integrates both features of the existing two models to cater for the needs of the language teachers and ESL writers. All the research studies that explored GM approached the topic from an ontological perspective rather than pedagogical. This particular study, on the other hand, aims to develop an approach to teaching GM. As a result, the study proposes an integrated approach not only for theoretical purposes but also pedagogical purposes.

\section{Pedagogical Implications}

The theorization and application of GM has implications for researchers. Researchers who are exploring the development of GM in language development and language education need to be aware of their theoretical orientation towards GM as the types of GM vary considerably depending on the model that theorize GM. This has two implications; firstly this would make the job of the researcher easier as she will be aware of the theoretical underpinnings of GM models. At this point, researchers have tree options: following the stratal model, adopting the semantic model or theorizing their own. Closely related to the first implication, being more knowledgeable about the model adopted for GM research will make it easier to identify the types of GM. The third implication for researchers is that the theoretical orientation towards GM will also help researchers in their data analysis methods. It is possible to track language 
development using basic text analysis. In the literature, frequently used method is tracking class shifted lexicogrammatical categories (transcategorization) and also creating more incongruent alternatives to metaphorical wordings (creating agnates). This might be straightforward while working on small number of texts. The softwares UAM Corpus Tool and NVivo are quite convenient. However, it is also be reasonable to apply data analysis methods of corpus linguistics to track instances GM and distinguish GM instances from dead metaphors and technical terms.

\section{Conclusion}

This paper firstly aimed to present how GM has been categorized in SFL and the second aim of the paper was to group the research that investigated the development of GM. Theorization of GM was followed by research studies that explored the role of GM in language development and language education contexts in relation to their GM model adopted. As an addition to GM research, the paper also presented the findings of a recent study that developed an approach to teaching grammatical metaphor retheorizing GM. Following a recounting of that particular study, the paper concluded with a discussion and pedagogical implications.

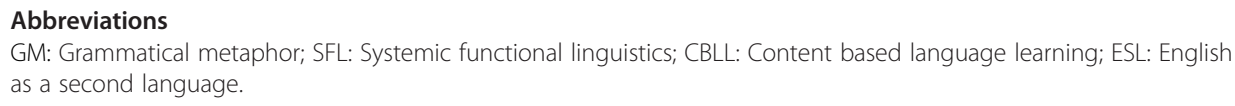

\section{Acknowledgements}

This paper is based on my Ph.D. research. I would like to express my gratitude for Jim Martin for sharing his knowledge and expertise with me. The views expressed herein are those of mine. I would also like to thank my colleague Mary Macken-Horarik for her suggestions and comments on earlier versions of this paper.

Received: 18 December 2014 Accepted: 6 May 2015

Published online: 28 May 2015

References

Bernstein, BB. 1975. Class, codes and control. III. Towards a theory of educa6onal transmissions. London: Routledge and Kegan Paul (Primary Socialisation, language and Education).

Burns, A. 2010. Action research. In Continuum companion to research methods in applied linguistics, ed. B Paltridge and A Phakiti, 80-97. London: Continuum.

Byrnes, H. 2009. Emergent L2 German writing ability in a curricular context: A longitudinal study of grammatical metaphor. Linguistics and Education 20: 50-66.

Christie, F, and B Derewianka. 2008. School Discourse: Learning to Write across the Years of Schooling. London: Continuum.

Colombi, MC. 2006. Grammatical metaphor: Academic language development in Latino students of Spanish. In Advanced language learning: The contribution of Halliday and Vygotsky, ed. H Byrnes, 147-163. London: Continuum.

Derewianka, B. 2003a. Grammatical metaphor in the transition to adolescence. In A.-M. Simon-Vandenbergen, M. Tavernier, \& L. Ravelli (Eds.), Grammatical metaphor: Views from systemic functional linguistics, (pp. 185-219). Amsterdam/Philadelphia: Benjamins.

Devrim, DY. 2013. Development of grammatical metaphor in academic literacy though online language support. Australia: Unpublished Ph.D. dissertation, University of Sydney.

Freebody, P. 2003. Qualitative research in education: Interaction and practice. London: Sage Press.

Halliday, MAK. 1985. Introduction to functional grammar. London: Arnold.

Halliday, MAK. 1988. On the language of physical science. In Registers of written English, ed. M Ghadessy. London: Pinter.

Halliday, MAK. 1998. Things and relations: regrammaticising experience as technical knowledge. In Reading science: Critical and functional perspectives on discourse of science, ed. JR Martin and R Veel, 185-235. London: Routledge.

Halliday, MAK, and R Hasan. 1976. Cohesion in English. London: Longman.

Halliday, MAK, and JR Martin. 1993. Writing science: Literacy and discursive power. London: The Falmer Press.

Halliday, MAK. 1994. Introduction to Functional Grammar, 2nd edition, London: Edward Arnold.

Halliday, MAK, and CMIM Matthiessen. 1999. Construing experience through meaning: A language-based approach to cognition. London: Cassell.

Kemmis, S, and R McTaggart. 1988. The action research planner. Victoria, Australia: Deakin University Press.

Martin, JR. 1992. English text: System and structure. Amsterdam: John Benjamins. 
Martin, JR. 1993. Technology, bureaucracy and schooling: Discursive resources and control. Cultural Dynamics 6(1): 84-130 Martin, JR, and D Rose. 2003. Working with discourse: Meaning beyond the clause. London, New York: Continuum. Martin, JR, and D Rose. 2008. Genre relations: Mapping culture. London: Equinox.

Mahboob, A, S Dreyfus, S Humphrey, and JR Martin. 2010. Appliable linguistics and English language teaching: the Scaffolding Literacy in Adult and Tertiary Environments (SLATE) project. In Appliable Linguistics, ed. A Mahboob and N Knight, 25-43. London: Continuum.

Mohan, B, and GH Beckett. 2001. A functional approach to research on content- based language learning: Recasts in causal explanations. Canadian Modern Language Review 58: 133-155.

Painter, C. 2003. The use of a metaphorical mode of meaning in early language development. In Grammatical metaphor: Views from systemic functional linguistics, ed. A-M Simon-Vandenbergen, M Taverniers, and L Ravelli, 151-167. Amsterdam/Philadelphia: Benjamins.

Ryshina-Pankova, M. 2010. Toward mastering the discourses of reasoning: use of grammatical metaphor at advanced levels of foreign language acquisition. Modern Language Journal 9(ii): 181-197.

Schleppegrell, MJ. 2004. Technical writing in a second language: The role of grammatical metaphor. In Analysing academic writing: Contextualized framework, ed. LJ Ravelli and RA Ellis, 173-189. New York: Continuum.

Torr, J, and A Simpson. 2003. The emergence of grammatical metaphor: Literacy- oriented expressions in the everyday speech of young children. In Grammatical metaphor: Views from systemic functional linguistics, ed. A-M Simon-Vandenbergen, M Taverniers, and L Ravelli, 169-183. Amsterdam/Philadelphia: Benjamins.

Vygotsky, L. 1978. Mind in society: The development of higher psychological processes. London: Harvard University Press.

Submit your manuscript to a SpringerOpen ${ }^{\circ}$ journal and benefit from:

- Convenient online submission

- Rigorous peer review

- Immediate publication on acceptance

- Open access: articles freely available online

- High visibility within the field

- Retaining the copyright to your article 